\title{
The Patterns of Korea's Foreign Direct Investment in Vietnam
}

\author{
Ji Hyun Oh'1, Jai S. Mah²* \\ ${ }^{1}$ Department of Economics, Ewha Womans University, Seoul, South Korea \\ ${ }^{2}$ Division of International Studies, Ewha Womans University, Seoul, South Korea \\ Email: jsmah@ewha.ac.kr
}

How to cite this paper: Oh, J.H. and Mah, J.S. (2017) The Patterns of Korea's Foreign Direct Investment in Vietnam. Open Journal of Business and Management, 5, 253271.

https://doi.org/10.4236/ojbm.2017.52023

Received: February 25, 2017

Accepted: April 10, 2017

Published: April 14, 2017

Copyright (c) 2017 by authors and Scientific Research Publishing Inc. This work is licensed under the Creative Commons Attribution International License (CC BY 4.0).

http://creativecommons.org/licenses/by/4.0/

\section{(c) (†) Open Access}

\begin{abstract}
The Vietnamese economy has shown very rapid economic growth since Doi Moi, with a huge amount of foreign direct investment (FDI) inflows. Among them, Korea's outward FDI (OFDI) in Vietnam deserves more attention as the leading investor. This paper reveals the patterns of Korea's OFDI in Vietnam. The pre-eminence of Korean FDI in Vietnam was the consequence of multiple events, including the coinciding efforts of both governments to promote FDI and Vietnam's provision of an alternative to China in the manufacturing sector. Korean firms have contributed to economic growth, employment generation and technology transfers in Vietnam. Vietnam can enhance the FDI inflows by overcoming the remaining instabilities in its economy, strengthening the level of human capital and sustaining its investor-friendly policies.
\end{abstract}

\section{Keywords}

Korea, FDI, Vietnam, Economic Growth, Employment

\section{Introduction}

Since the launch of the economic reform policy, Doi Moi, in 1986, Vietnam has made expansive efforts to transform its centrally planned economy into a market-oriented system, and the annual average real gross domestic product (GDP) growth rate was recorded as 6.5 percent during the period 1986-2013. The reform initiative took place among diverse sectors, involving investment, trade and state-owned enterprise (SOE) policies [1]. Regarding investment, beginning with the establishment of the Law on Foreign Investment in 1987, Vietnam unified the different legislation on domestic and foreign firms into the $2005 \mathrm{New}$ Investment Law [2] [3]. Laws regarding SOEs were established or revised to minimize the power of the Government, promote the private and foreign sectors and equalize the treatments granted to the three participants [1]. Changes in in- 
ternational economic relations, such as joining the Association of South East Asian Nations (ASEAN), the Asia-Pacific Economic Cooperation (APEC) and the World Trade Organization (WTO) and signing other bilateral agreements, reflected the effort of the Vietnamese Government to promote its Doi Moi initiative.

As Vietnam actively participated in the world economy, a huge amount of foreign direct investment (FDI) flowed into it. According to the United Nations Conference on Trade and Development (UNCTAD) statistics, Vietnam's stock of FDI grew from USD 1billion in 1992 to USD 10billion in 1997. Although the Vietnamese economy went through a crisis and faced limits in its reform policies, Vietnam was relatively successful in maintaining its status as an attractive investment destination, with its FDI stock exceeding USD 80billion in 2013.

On the other hand, the amount of outward FDI (OFDI) from Korea has increased significantly. The motives of Korean firms to invest abroad included efficiency-seeking, market searching due to the limited size of the domestic market, active support from the Government and institutional aid [4] [5]. Starting from USD 2 billion in 1990, Korea's OFDI in stock values reached USD 219 billion in 2013. Such a performance of Korea in OFDI is remarkable when discussing Vietnam's FDI inflows, as Korea is currently the leading investor in Vietnam. Although China remains the leading recipient of Korea's OFDI in Asia, Vietnam is strengthening its position, as it ranked the fourth-largest destination for Korean FDI in the world as of 2014. The accumulated amount of Korea's OFDI towards Vietnam exceeded USD 10billion in the same year [6]. With China gradually losing its competitive advantage in low labor costs [7], Vietnam deserves more attention as the alternate recipient of Korea's OFDI. Despite the importance and peculiarity of Korea's OFDI in Vietnam, its pattern has rarely been analyzed rigorously. The current paper tries to fill such a gap by revealing the patterns of Korea's OFDI in Vietnam over the past three decades.

The structure of this paper is as follows: Section II overviews FDI in Vietnam. Section III describes Korean OFDI. The patterns of Korea's FDI in Vietnam are explained in Section IV. Section V covers the impact of Korea's FDI on the Vietnamese economy. Policy implications are explained in Section VI and conclusions are provided in Section VII.

\section{Overview of FDI in Vietnam}

Vietnam's economic interactions with other countries were highly regulated until the mid-1980s under a centrally planned economy. In the meantime, its economic growth performance was poor [7]. As Vietnam transformed its economy with the Doi Moi initiative, the Vietnamese economy showed an annual average economic growth rate of 6.5 percent between 1986 and 2013. Since FDI liberalization has been one of the main features of the structural reform, the effectiveness of Doi Moi may be assessed by understanding the patterns of Vietnam's FDI inflows.

Table 1 shows the total FDI flows into Vietnam from 1988 to 2013. The first 
Table 1. FDI projects licensed in Vietnam.

\begin{tabular}{ccc}
\hline Year & Number of Projects & Implemented FDI (USD million) \\
\hline 1988 & 37 & - \\
1990 & 107 & 574.9 \\
1992 & 196 & 2240.6 \\
1994 & 372 & 2938.2 \\
1996 & 372 & 2372.4 \\
1998 & 285 & 2398.7 \\
2000 & 391 & 2884.7 \\
2002 & 808 & 2708.4 \\
2004 & 811 & 4100.4 \\
2006 & 987 & $11,500.2$ \\
2008 & 1171 & $11,000.3$ \\
2010 & 1237 & $10,046.6$ \\
2012 & 1287 & $11,500.0$ \\
2013 & 1530 & $111,692.9$ \\
$1988-2013$ & 17,223 & $2014), 4 a n:$ GsO \\
\hline
\end{tabular}

Source: Vietnam General Statistics Office (GSO), Statistical Handbook (2005-2014), Hanoi: GSO.

few years from 1988 to 1991 showed a rather slow rate of increase, with the number of projects remaining around 90 on average. The actually implemented FDI inflows remained under USD 1 billion each year until 1992 compared with USD 10billion in 1996. Such poor performance could be attributed to the instability of the Vietnamese economy from 1988 to 1991, involving hyperinflation, food shortage and the breaking down of the communist bloc [3]. Nonetheless, the reform started to show progress, as the FDI inflows surged from 1992. The FDI inflows had more than doubled in 1994 and reached their peak at USD 3.3 billion in 1997. However, Vietnam could not bypass the fatal effect of the 1998 Asian financial crisis [3] [8]. The slowdown in FDI inflows immediately after the Asian crisis was inevitable due to the fact that Vietnam's main investors consisted of Asian countries, such as Japan, Korea and Singapore [7].

The FDI inflows began to recover in the mid-2000s. Although the Vietnamese regulations on mergers and acquisitions (M\&As) were still against the emerging demands of foreign investors, who preferred them as an alternative method of investment after the crisis [7], new motivations to invest in Vietnam existed both internally and externally. Internally, the 20 percent surge of FDI in 2005-2006 can be attributed to the 2005 Investment Law and Enterprises Law, which equalized the playing field for foreign investors by providing equal treatment [3]. Externally, Vietnam signed a bilateral trade agreement (BTA) with the United States in 2001. Thanks to the pre-eminence of the United States as an export destination of many investing countries, Vietnam emerged as an attractive ground for production and exportation after the establishment of its BTA [7] 
[9]. The FDI inflows began to surge with Vietnam's WTO accession, reaching their peak of over US $\$ 11$ billion in 2008. Vietnam's commitment to the WTO provisions additionally attracted foreign investors [1] [4].

The surge in FDI inflows in the years 2007 and 2008 can be partly explained by other factors, such as Vietnam's cheap labor compared with the rising wage level of China, Vietnam's passing of new legislation facilitating operate and transfer (BOT) agreements for foreigners and stronger regional integration among Asian countries [4] [10]. The amount of FDI inflows has continued to exceed USD 10 billion since 2008. In 2013, it amounted to USD 11.5 billion, accounting for 19.5 percent of the GDP.

Both Vietnam and its neighboring countries, that is, Cambodia, Lao PDR and Myanmar, have the potential to attract FDI due to their cheap labor. Vietnam is noteworthy in its performance among those countries, as Table 2 shows. Investment in Vietnam accounted for more than three-quarters of the FDI flows into those four countries in Southeast Asia during the period 1995-2013. The fact that Vietnam has outperformed its neighboring countries, such as Lao PDR, Cambodia and Myanmar, with lower labor costs implies that wages are not the single driver of foreign investors' choice of investment destinations [5].

Table 3 shows the shares of FDI flows into Vietnam by the main sectors. It displays a concentrated pattern, with the leading manufacturing sector constituting 47.2 percent of the total registered capital as of 2013. The proportion of the manufacturing sector in FDI inflows tended to fall until 2009, with the lowest record of 12.8 percent, but its share soon recovered and surged to 76.7 percent of Vietnam's total FDI in 2013. This pattern of concentration in the manufacturing sector depicts the motives of foreigners investing in Vietnam as a production and export platform. Compared with China as the center of manufac-

Table 2. FDI flows into vietnam and neighboring countries (unit: USD million).

\begin{tabular}{ccccc}
\hline year & Vietnam & Cambodia & $\begin{array}{c}\text { Lao } \\
\text { PDR }\end{array}$ & Myanmar \\
\hline 1995 & $1780(76.2)$ & 151 & 88 & 318 \\
1997 & $2587(69.5)$ & 168 & 86 & 879 \\
1998 & $1700(63.6)$ & 243 & 45 & 683 \\
1999 & $1484(71.6)$ & 232 & 52 & 304 \\
2000 & $1289(76.7)$ & 149 & 34 & 208 \\
2005 & $2021(75.8)$ & 381 & 28 & 236 \\
2010 & $8000(70.4)$ & 783 & 333 & 2249 \\
2011 & $7519(69.8)$ & 892 & 301 & 2057 \\
2012 & $8368(72.3)$ & 1557 & 294 & 1354 \\
2013 & $8900(67.3)$ & 1275 & 427 & 2621 \\
$1995-2013$ & $77,330(73.6)$ & 9339 & 2960 & 15,497 \\
\hline
\end{tabular}

Notes: percent of Vietnam's shares in CLMV in the parentheses. CLMV denotes Cambodia, Lao PDR, Myanmar and Vietnam. Source: ASEAN, Statistical Yearbook (2003, 2008, 2013), Singapore: ASEAN Secretariat. 
Table 3. FDI inflows by main economic activities in Vietnam, total registered capital (unit: USD million).

\begin{tabular}{|c|c|c|c|c|c|c|}
\hline sectors & 2005 & 2007 & 2009 & 2011 & 2013 & $\begin{array}{c}\text { 1988-2013 accumulated } \\
\text { amount }\end{array}$ \\
\hline $\begin{array}{c}\text { Agriculture, } \\
\text { forestry and } \\
\text { fishing/mining and quarrying }\end{array}$ & $107.1(1.6)$ & $320.9(1.5)$ & $481.9(2.1)$ & $239.9(1.5)$ & $183.8(0.8)$ & $15,934.0(5.9)$ \\
\hline Manufacturing & $4,818.4(70.4)$ & $10,882.5(51.0)$ & $2,969.2(12.8)$ & $7,788.8(49.9)$ & $17,141.2(76.7)$ & $126,828.0(47.2)$ \\
\hline Construction & $171.1(2.5)$ & $993.3(4.7)$ & $487.4(2.1)$ & $1,296.4(8.3)$ & $222.3(1.0)$ & $\begin{array}{c}11,468.2 \\
(4.3)\end{array}$ \\
\hline $\begin{array}{l}\text { Wholesale and } \\
\text { retail trade; } \\
\text { repair of motor } \\
\text { vehicles and } \\
\text { motorcycles, }\end{array}$ & $99.3(1.5)$ & $129.9(0.6)$ & $238.2(1.0)$ & $499.1(3.2)$ & $628.8(2.8)$ & $3,297.7(1.2)$ \\
\hline$\left(\right.$ Transportation and storage ${ }^{\mathrm{a}}$ ) & $684.2(10.0)$ & $356.5(1.7)$ & $277.7(1.2)$ & $74.9(0.5)$ & $68.1(0.3)$ & $8483.2(3.2)$ \\
\hline $\begin{array}{l}\text { Accommodation and food } \\
\text { services }\end{array}$ & $61.8(0.9)$ & $1968.1(9.2)$ & $8794.2(38.1)$ & $476.8(3.1)$ & $248.9(1.1)$ & $18,914.4(7.0)$ \\
\hline $\begin{array}{l}\text { Real estate } \\
\text { activities }\end{array}$ & $460.8(6.7)$ & $6114.8(28.6)$ & $7739.1(33.5)$ & $869.9(5.6)$ & $951.9(4.3)$ & $56,263.3(20.9)$ \\
\hline $\begin{array}{l}\text { Professional, scientific and } \\
\text { technical activities }\end{array}$ & - & - & - & $265.5(1.7)$ & $437.7(2.0)$ & $873.5(0.3)$ \\
\hline Total & 6840.0 & $21,348.8$ & $23,107.5$ & $15,618.7$ & $22,352.2$ & $268,691.6$ \\
\hline
\end{tabular}

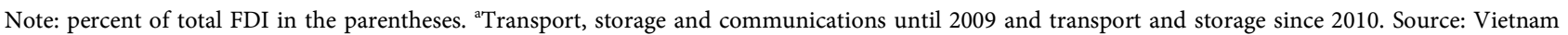
GSO, Statistical Handbook (2005-2014), Hanoi: GSO.

turing production of the world, Vietnam has managed to act as a successful alternative with a comparative advantage in lower wages. Regarding the sub-categories of the manufacturing sector, recent investments have tended to diverge from the production of garments to the production of electronic products [5] [7].

Other than manufacturing, investment in real estate ranked second. Although real estate recently showed a decreasing trend after its peak during the years 2007-2009, its total registered capital remained larger than that of the other economic activities [9]. Accommodation and food-related activities have consistently attracted foreign investors. Agriculture, forestry, fishing, mining and quarrying, construction, and transportation and storage have all shown steady performances without many remarkable changes in the share of FDI inflows throughout the period.

Table 4 shows the accumulated FDI flows into Vietnam by regions and the top 10 provinces hosting FDI as of the end of 2014. The regional trend of FDI inflows has not changed much over the years since the late1980s. Vietnam's regions can largely be divided into the northern part and the southern part, the former with cheap and abundant labor and the latter with a developed local market. Each region in Vietnam provides different incentives for investors. The Vietnamese Government has established industrial zones (IZs) and export processing zones (EPZs) in various regions, which offer a developed infrastructure as well as land and tax incentives to foreigners investing in those zones [2]. 
Table 4. Total FDI projects licensed by province in Vietnam, accumulation of projects having effect as of the end of 2014.

\begin{tabular}{|c|c|c|}
\hline province & $\begin{array}{l}\text { number of projects } \\
\text { (percent) }\end{array}$ & $\begin{array}{l}\text { total registered capital } \\
\text { in USD million } \\
\text { (percent) }\end{array}$ \\
\hline Total & $17,768(100.0)$ & $252,716.0(100.0)$ \\
\hline South East & $9692(54.5)$ & $110,528.8(43.7)$ \\
\hline Ho Chi Minh City & 5271 & $38,275.8$ \\
\hline Ba Ria-Vung Tau Province & 303 & $26,810.2$ \\
\hline Dong Nai Province & 1241 & $21,645.4$ \\
\hline Binh Duong Province & 2513 & $20,086.4$ \\
\hline Red River Delta & $5290(29.7)$ & $63,350.5(25.0)$ \\
\hline Hanoi & 3051 & $23,824.7$ \\
\hline Haiphong & 452 & $11,281.2$ \\
\hline Bac Ninh Province & 566 & 7668.6 \\
\hline $\begin{array}{l}\text { North Central and Central coastal } \\
\text { areas }\end{array}$ & $1086(6.1)$ & $51,215.3(20.2)$ \\
\hline Ha Tinh Province & 59 & $10,653.9$ \\
\hline Thanh Hoa Province & 56 & $10,276.0$ \\
\hline Mekong River Delta & $979(5.5)$ & $12,189.1(4.8)$ \\
\hline $\begin{array}{l}\text { Northern midlands and mountain } \\
\text { areas }\end{array}$ & $518(2.9)$ & $11,742.0$ \\
\hline Thai Nguyen Province & 76 & 6910.3 \\
\hline Central Highlands & $148(0.8)$ & $819.8(0.3)$ \\
\hline
\end{tabular}

Note: percent of total FDI in the parentheses. Source: Vietnam GSO, Statistical Handbook (2014), Hanoi: GSO.

The southeast region of Vietnam has been the largest investment location so far, with 43.7 percent of the total capital registered in that area as of the end of 2014. Particularly, the existence of a large local demand around Ho Chi Minh City is the most important motive for FDI in the southeast region [2]. The Red River Delta in the north comes in the second place with 25.0 percent of the registered capital flowing into the region. The southeast and the Red River Delta share commonalities in that they are the regions with the most developed infrastructure and high-quality labor in Vietnam [7]. Both regions have advanced transport and telecommunication systems, technology and services, which greatly reduce the production costs of foreign investors [11].

The reason that good infrastructure is concentrated in those two regions is that these regions possess most of the IZs and EPZs in Vietnam. The effectiveness of IZs and EPZs in attracting FDI is supported by the fact that 45 percent and 19 percent of the FDI flowing into the southeast and Red River Delta regions were destined for those zones, respectively, as of 2007. The FDI inflows have been spreading out to provinces and cities other than Ho Chi Minh City and Hanoi due to the rising production costs and difficulties involved in obtaining 
land. Meanwhile, fiscal incentives have proved to be generally unsuccessful in attracting FDI to remote areas [7].

Table 5 illustrates the main countries of origin of Vietnam's FDI inflows. The predominance of Asian countries in investment in Vietnam has a long history, with three-fifths of the total registered capital coming from Asia during the period 1988-2006 [7]. The recent patterns have also followed this trend, with Korea, Japan, Singapore, Taiwan and China being the top investors. Those five East Asian economies have accounted for more than half of the total FDI in Vietnam since the mid-2000s. Korea and Japan lead the investment, as each of them takes up more than 13 percent of Vietnam's total FDI inflows. In 2014, Korea alone accounted for 35 percent of the FDI flows into Vietnam.

Although investment from the United States to Vietnam continued to increase after the signing of their BTA, the amount of its registered capital in Vietnam still lags behind that of the other Asian investors. This is mainly due to the fact that many American and European firms invest in Vietnam via Asian countries such as China, including Hong Kong and Singapore, through licensing instead of investing directly in Vietnam [7]. Similarly, the share of Korea in the FDI flows into Vietnam would actually have been larger than 35 percent in 2014 in the sense that the largest Korean investor in Vietnam, Samsung Electronics, invested in Vietnam through its subsidiary established in Singapore [9].

\section{Overview of Korean OFDI}

In Korea, OFDI remained restrained until 1979. The liberalization of OFDI was achieved in the 1980s with simplified procedures. As trade surplusesbegan to be recorded in 1986, the Korean Government started to promote it actively [12] [13]. The rising wage level and continuing trade surpluses since the end of the 1990s expedited Korean firms' OFDI.

The amount of OFDI tended to increase between 1990 and 2014. The amount of OFDI jumped to USD 22 billion in 2007 and has recorded over USD 20 billion

Table 5. Total registered capital licensed by investors in Vietnam (unit: USD million).

\begin{tabular}{cccccccc}
\hline & 2006 & 2008 & 2010 & 2012 & 2013 & 2014 & $\begin{array}{c}2005-2014 \\
(\%)\end{array}$ \\
\hline Korea & 3106.5 & 2019.0 & 2545.2 & 1285.2 & 4466.0 & 7705.0 & $30,652.9(13.8)$ \\
Japan & 1490.4 & 7578.7 & 2399.0 & 5593.1 & 5875.5 & 2299.0 & $30,561.6(13.7)$ \\
Singapore & 675.3 & 4495.8 & 4585.6 & 1938.0 & 4769.0 & 2892.8 & $25,201.5(11.3)$ \\
$\begin{array}{c}\text { Taiwan } \\
\text { United States }\end{array}$ & 845.8 & 8851.7 & 1453.1 & 2658.1 & 637.3 & 1228.9 & $20,909.8(9.4)$ \\
$\begin{array}{c}\text { China } \\
\text { (incl. Hong }\end{array}$ & 2094.3 & 782.5 & 933.7 & 1100.3 & 3068.5 & 3533.5 & $18,700.6(8.4)$ \\
Kong) & & & & & & & \\
Total & $12,003.8$ & $64,011.0$ & $19,886.1$ & $16,348.0$ & $22,352.2$ & $21,921.7$ & $221,790.6$ \\
\hline
\end{tabular}

Note: percent of total FDI in the parentheses. Source: Vietnam GSO, Statistical Handbook (2005-2014), Hanoi: GSO. 
each year ever since then. The driving engine of OFDI after 2005 was the active promotion plan of the Government, in which the limit on the amount of investment was relaxed, better insurance policies were provided and increased financial support became available for investors [13]. Asia has been the largest recipient of Korean FDI. The ratio of OFDI in Asia divided by that in the world equaled 42.4 percent during the period 1990-2014 [12]1.

Manufacturing has long been the leading sector in Korea's OFDI, accounting for 43.7 percent of the total amount of investment in 1990, and its share of the total FDI increased to over 50 percent on average between 1994 and 2006. The share of manufacturing in the total OFDI of Korea has decreased since the second half of the 2000s to record 27.1 percent in 2014. Such a declining trend of investment in the manufacturing sector can be attributed to the rising labor costs and environmental regulations of China, traditionally the largest recipient in manufacturing, which greatly impeded Korea's overall investment in it [14] $]^{2}$. The decreasing share of manufacturing is also associated with the expansion of the mining and quarrying sector since 2006. Investment in mining and quarrying increased to account for 21.7 percent of the total OFDI between 2006 and 2014. Such a rise in it was due to the increase in large-scale resource development projects, mostly concerning crude oil and natural gas [15] [16].

China has led in hosting FDI from Korea among all the Asian economies since 1992, as is shown in Table 6. China, even excluding Hong Kong, is Korea's second-largest investment destination following the United States as of 2014, with USD 49 billion accumulated OFDI. Vietnam ranks third among the Asian countries, constituting 9.4 percent of Korea's OFDI in Asia from 1992 to 2014. Although it lags behind China, Korea's investment in Vietnam has risen consistently and reached USD 1.6 billion in 2014. This performance by Vietnam can be attributed to its ability to satisfy the investors' demands with a highly educated population compared with its neighboring countries in southeast Asia [17]. During the period 2007-2014, Vietnam's share increased to 10.6 percent of Korea's OFDI in Asia on average, almost doubling its share from 1988 to 2005, 5.4 percent.

Table 6. Korean OFDI in asia by countries, invested amount (unit: USD million).

\begin{tabular}{cccccc}
\hline Year & China (incl. Hong Kong) & Vietnam & Indonesia & Singapore & Asia \\
\hline 1992 & $184(32.4)$ & $16(3.0)$ & $214(37.8)$ & $13(2.4)$ & 568 \\
1995 & $957(54.3)$ & $183(10.4)$ & $207(11.8)$ & $22(1.3)$ & 1764 \\
2000 & $1035(60.5)$ & $71(4.2)$ & $118(6.9)$ & $108(6.3)$ & 1710 \\
2005 & $3242(74.6)$ & $325(7.5)$ & $111(2.6)$ & $126(2.9)$ & 4345 \\
2010 & $4952(48.7)$ & $857(8.4)$ & $927(9.1)$ & $401(3.9)$ & 10,179 \\
2012 & $5655(49.3)$ & $969(8.4)$ & $998(8.7)$ & $381(3.3)$ & 11,476 \\
2014 & $3752(42.0)$ & $1558(17.5)$ & $715(8.0)$ & $918(10.3)$ & 8926 \\
$1992-2014$ & $64,586(55.0)$ & $11,143(9.4)$ & $7638(6.5)$ & $6142(5.2)$ & 117,348 \\
\hline
\end{tabular}

Note: percent of each country in Asia in the parentheses. Source: Korea EXIM bank database.

${ }^{1}$ Source: Korea EXIM bank database.

${ }^{2}$ Source: Korea EXIM bank database. 


\section{The Patterns of Korea's FDI in Vietnam}

As Korea's fourth-largest investment destination as of 2014, Vietnam is noteworthy among Korea's overall OFDI. The first bilateral economic agreement between Korea and Vietnam after the communization of Vietnam dates back to 1993, and the two parties concluded the Korea-Vietnam Free Trade Agreement (FTA) in May 2015. The amount of investment and trade between the two countries has increased significantly over the years. With Vietnam's opening up to FDI via the Doi Moi initiative and the Korean Government's active promotion of OFDI, Korea's FDI in Vietnam has surged over the last 23 years to USD 11 billion in its accumulated amount as of the end of 2014.

Table 7 shows the trend of Korea's OFDI in Vietnam. The invested amount increased quickly to reach USD 183 million in 1995, which is more than 10 times the amount in 1992. The rising trend continued until 1997. The bilateral investment treaty (BIT) established in 1993 between Korea and Vietnam, which is traditionally thought as an effective accelerator of FDI [12], would have contributed to this trend. However, due to the 1998 economic crisis in Korea, the amount of Korea's OFDI in Vietnam decreased during the period 1998-2001 to the annual average of USD 64 million [18].

Korea's OFDI in Vietnam began to recover in 2002, apparently due to the increasing foreign exchange reserves of Korea as a result of continuing trade surpluses and Vietnam's settlement of its international economic relationship with the United States. The effort of the Vietnamese Government to increase the local government autonomy in authorizing FDI projects also contributed to the recovery [19]. Korea's OFDI in Vietnam increased to over USD 1 billion each year,

Table 7. Korea's OFDI in Vietnam.

\begin{tabular}{cccc}
\hline year & $\begin{array}{c}\text { number } \\
\text { of approval }\end{array}$ & $\begin{array}{c}\text { number of } \\
\text { new overseas } \\
\text { enterprises }\end{array}$ & $\begin{array}{c}\text { invested amount } \\
\text { (USD million) }\end{array}$ \\
\hline 1992 & 23 & 8 & 16 \\
1994 & 73 & 44 & 90 \\
1996 & 90 & 41 & 124 \\
1998 & 40 & 3 & 80 \\
2000 & 69 & 27 & 71 \\
2002 & 190 & 100 & 160 \\
2004 & 265 & 110 & 183 \\
2006 & 574 & 269 & 597 \\
2008 & 828 & 287 & 1375 \\
2010 & 772 & 215 & 857 \\
2012 & 752 & 195 & 969 \\
2014 & 1252 & 3226 & 158 \\
$1992-2014$ & 9114 & & \\
\hline
\end{tabular}

Source: Korea EXIM bank database. 
with only a few exceptional years since 2007. The slowdown in 2009 and 2010 reflected the global financial crisis. In 2014, it reached USD 1.6 billion. The Korea-ASEAN FTA on investment that came into effect in 2009 was an external motivator that opened Vietnam's investment sector even more to the Korean investors. More recently, both countries succeeded in signing the Korea-Vietnam FTA in May2015 [6].

Table 8 shows that Vietnam is noteworthy among four developing economies in southeast Asia in attracting Korea's OFDI. In 2003, the share of Vietnam reached its highest point with 98.9 percent of the total amount of Korea's OFDI in CLMV. Overall, Vietnam accounted for 82.3 percent of Korea's total investment in CLMV countries during the years 2001-2011, clearly denoting Vietnam and Korea's close investment relations compared with the other three developing countries. It is also comparable with the data appearing in Table 2 on the FDI flows from the world as a whole, in which Vietnam accounted for 73.6 percent of the FDI into CLMV during the same period. Even though Vietnam still had the lion's share in the case of the OFDI from the world as a whole, its proportion was about 10 percent higher in the case of that from Korea. Vietnam has thus become particularly notable in the context of OFDI from Korea.

For Korea, the FDI in Vietnam in some years even exceeded Korea's OFDI in the ASEAN5 countries, that is, Indonesia, Malaysia, the Philippines, Singapore and Thailand. In the years 1998, 2000 and 2008, Korea's investment in Vietnam alone outweighed the total outflows into those five countries. This can be compared with the fact that Vietnam accounted for less than one-tenth of the FDI flows into the ASEAN5 from the world, as seen in Table 2. It clearly shows that Korea exceptionally values Vietnam as an investment destination more than the

Table 8. Korea's OFDI in Vietnam, CLMV and ASEAN, net flows (unit: USD million).

\begin{tabular}{ccccc}
\hline year & $\begin{array}{c}\text { Vietnam } \\
\text { (percent of CLMV) }\end{array}$ & CLMV & ASEAN5 & $\begin{array}{c}\text { ASEAN } \\
\text { Total }\end{array}$ \\
\hline 2001 & $52(83.9)$ & 62 & -302 & -240 \\
2002 & $56(56.6)$ & 99 & 69 & 177 \\
2003 & $175(98.9)$ & 177 & 372 & 550 \\
2004 & $163(92.6)$ & 176 & 646 & 828 \\
2005 & $96(57.1)$ & 168 & 338 & 529 \\
2006 & $484(76.6)$ & 632 & 658 & 1290 \\
2007 & $1358(90.2)$ & 1505 & 940 & 2445 \\
2008 & $655(59.9)$ & 1094 & 437 & 1532 \\
2009 & $613(78.4)$ & 782 & 1007 & 1789 \\
2010 & $1336(96.5)$ & 1384 & 2321 & 3705 \\
2011 & $750(84.2)$ & 891 & 1661 & 2552 \\
$2001-2011$ & $5738(82.3)$ & 6970 & 8147 & 15,157 \\
\hline
\end{tabular}

Notes: CLMV denotes Cambodia, Lao PDR, Myanmar and Vietnam. ASEAN5 comprises of Indonesia, Malaysia, Philippines, Singapore, and Thailand. Source: ASEAN, Statistical Yearbook, (2003, 2008, 2013), Singapore: ASEAN. Secretariat. 
other countries of the world.

Manufacturing has been the most important sector, with a share of 56.8 percent of the accumulated amount during the period 1992-2014. Until 1999, the manufacturing sector accounted for 77.5 percent of Korea's total OFDI in Vietnam. It is interesting to note that, although the amount of investment increased rapidly again to reach its maximum of USD 975 million in 2014, the share of the manufacturing sector in the overall OFDI has shrunk since 2004. This pattern can partly be attributed to the diversification of Korea's investment by sector. Economic activities such as wholesale and retail trade have shown gradual growth over the years ${ }^{3}$.

Mining and quarrying is another industry in Vietnam in which the growth of Korea's investments is notable, among others. Unlike the first decade, when it accounted for less than 1 percent of Korea's investment, it attracted 20.4 percent during the years 2005-2014. This is consistent with the fact that Vietnam was one of the five leading host countries ${ }^{4}$ of Korean public institutions' resource development projects, the investments of which mostly concentrated on mining activities. The entry of Korea's public institutions into Vietnam is interesting in the sense that the projects related to those activities were mostly destined for countries in North America or Europe [20].

The FDI inflows by the sub-categories of the manufacturing sector have changed noticeably over the years, as shown in Table 9. In general, Korea's FDI in Vietnam's manufacturing sector recently diversified into various industries compared with the 1990s and early2000s, when they were mostly concentrated on garments and shoes. The accumulated share of textiles and footwear accounted for 49.7 percent of the FDI in the manufacturing sector on average from 1992 to 2005 but dropped to 26.7 percent from 2006 to 2014 . As an accumulated amount, it accounted for 30.2 percent of Korea's FDI in the manufacturing sector of Vietnam as of 2014. A clear comparison can be made with the metal industry, including both basic and fabricated metal, the proportion of which jumped from less than 10 percent with a few years of exceptions until 2005 to over 20 percent in general since then. Consequently, a large part of the decreased share of the garments and shoes sector can be attributed to Korea's increasing investment in the metal industry of Vietnam.

Electronics and telecommunications have been the leading industry in attracting Korea's manufacturing FDI in Vietnam, accounting for 25.1 percent between 1992 and 2014. Particularly in 2013 and 2014, they attracted nearly 40 percent of Korea's investment in the manufacturing sector of Vietnam. The fact that the share of Korea's investment in Vietnam's textile and shoes industry has been similar to that in the electronics and telecommunications industry is unique and different from the pattern of Korea's FDI in the world, where investment in electronics and telecommunications far outweighed that in garments and shoes by more than 20 percent. This difference in the investment 
Table 9. Korea's OFDI in vietnam by manufacturing sub-categories, invested amount (unit: USD million).

\begin{tabular}{|c|c|c|c|c|c|c|}
\hline$\stackrel{\vec{\Xi}}{\check{\nabla}}$ & 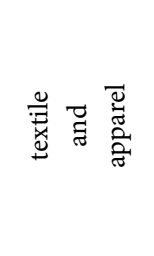 & 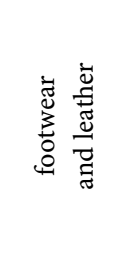 & $\begin{array}{l}\text { चँّ } \\
\text { घँ }\end{array}$ & 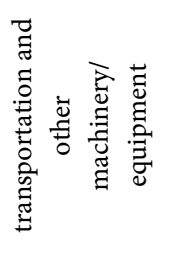 & 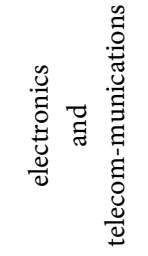 & 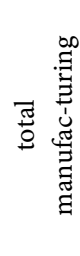 \\
\hline 1992 & $13(83.5)$ & $0(0.0)$ & $1(11.6)$ & $0(0.0)$ & $0(0.0)$ & 16 \\
\hline 1995 & $20(13.6)$ & $17(11.4)$ & $2(1.3)$ & $2(1.5)$ & $101(65.7)$ & 154 \\
\hline 2000 & $8(24.1)$ & $1(3.1)$ & $5(15.3)$ & $7(21.2)$ & $4(11.9)$ & 34 \\
\hline 2005 & $69(37.6)$ & $41(22.7)$ & $12(7.0)$ & $11(6.2)$ & $6(3.7)$ & 184 \\
\hline 2006 & $88(29.4)$ & $24(8.0)$ & 58 (19.6) & $11(3.7)$ & $42(14.2)$ & 300 \\
\hline 2007 & $112(18.1)$ & $28(4.6)$ & $175(28.2)$ & $34(5.6)$ & $122(19.7)$ & 621 \\
\hline 2008 & $140(20.2)$ & $44(6.4)$ & $140(20.1)$ & $30(4.4)$ & $147(21.2)$ & 696 \\
\hline 2009 & $60(19.2)$ & $15(5.0)$ & $34(10.8)$ & 77 (24.6) & $31(10.1)$ & 313 \\
\hline 2010 & $98(21.1)$ & $33(7.1)$ & $95(20.4)$ & $49(10.5)$ & $99(21.2)$ & 467 \\
\hline 2011 & $125(23.7)$ & $39(7.5)$ & $112(21.3)$ & $25(4.8)$ & $91(17.3)$ & 529 \\
\hline 2012 & $113(21.4)$ & $10(2.0)$ & $131(25.0)$ & $24(4.7)$ & $111(21.1)$ & 528 \\
\hline 2013 & $138(18.3)$ & $32(4.3)$ & $118(15.7)$ & $40(5.4)$ & $297(39.3)$ & 756 \\
\hline 2014 & $188(19.3)$ & 47 (4.9) & $68(7.0)$ & $50(5.2)$ & $386(39.7)$ & 975 \\
\hline $1992-2014$ & $1493(23.6)$ & $414(6.6)$ & 1007 (15.9) & $410(6.5)$ & $1587(25.1)$ & 6323 \\
\hline
\end{tabular}

Note: percent of total manufacturing OFDI in the parentheses. Source: Korea EXIM bank database.

pattern reflects the comparative advantage of Vietnam's cheap and abundant labor, which is the biggest motivation for Korean firms to invest in the country [18] [21]. Nonetheless, Korean investors are increasingly placing more emphasis on educated laborers than low-wage incentives, as they tend to shift their investment to high-technology manufacturing sectors such as electronics and transportation machinery [21].

As an example of the increasing importance of the electronics industry in Korea's OFDI in Vietnam, Samsung Electronics has become the largest investor in Vietnam. It established a factory producing mobile handsets near Hanoi, which exported as much as USD 24 billion in 2013. It also set up its second factory in the northern region of Vietnam in February 2014, which is expected to have R\&D functions in addition to production facilities. The total exports of Samsung Electronics in Vietnam reached USD 26 billion, accounting for 16.8 percent of Vietnam's total exports. About 45 percent of smart phones produced by Samsung Electronics were manufactured in Vietnam in 2014 [9].

The investment trends are strongly correlated with the changing motivations of Korean firms in choosing Vietnam as their investment destination. This occurs because different industries provide different kinds of advantages for foreign investors, as well as requiring different kinds of cost-saving factors. Some activities deserve more attention in terms of promoting exports, while others 
provide sales opportunities in the local market. Some sectors require cheap labor as the essential production factor, while others need a developed infrastructure, such as transportation facilities. Thus, the patterns of Korea's OFDI in Vietnam can be better understood by looking at the changing motivations of Korean investors, which are shown in Table 10.

Until 2006, export promotion was the most important motive of investors, with an average share of 37.9 percent, while access to the Vietnamese local market remained as low as 7.5 percent. This is consistent with the attitude of many other Asian countries, which saw Vietnam as an export ground for their products. For instance, the signing of the Vietnam-USA BTA led to the surge in Asian economies' FDI in Vietnam compared with the other regions [7].

The Korean investors' motive for entering the Vietnamese market started to exceed that of export promotion in 2007 and is currently the most important motive. Such shifts in investment purposes can be attributed to Vietnam's rapid economic growth and its growing middle class, which greatly increased the significance of the local demands of the Vietnamese economy [7]. Although the investment and export trend of electronics and telecommunications manufacturing illustrates that a large proportion of goods produced in Vietnam are still destined for exporting to other countries [7], large enterprises, such as Samsung Electronics, are increasingly driven by market-seeking motivations and target Vietnam's local consumers [5] [21].

Cheap labor has continued to be a dominant motive for Korean firms to invest in Vietnam, despite the recent decrease in its share. It accounted for 32.7 percent of Korean FDI as an accumulated amount during the period 1992-2014. Nevertheless, it is important that Vietnam's cheap labor should be understood in comparison with its quality. Specifically, Vietnam enjoys a low-wage incentive in the context of the rising wage in China but loses its advantage when compared with its neighboring countries, like Lao PDR and Myanmar [5]. The reason that Korean investors still perceive Vietnam's labor as a cost-efficient factor is that Vietnamese workers are relatively more educated than the workers in its competing, neighboring countries [17].

Table 10. Korea's OFDI in vietnam by investment motive, number of approval.

\begin{tabular}{cccccc}
\hline year & $\begin{array}{c}\text { resource } \\
\text { development }\end{array}$ & $\begin{array}{c}\text { export } \\
\text { promotion }\end{array}$ & $\begin{array}{c}\text { cheap } \\
\text { labor }\end{array}$ & $\begin{array}{c}\text { access } \\
\text { to local } \\
\text { market }\end{array}$ & total \\
\hline 1992 & $1(4.3)$ & $11(47.8)$ & $8(34.8)$ & $0(0.0)$ & 23 \\
1995 & $0(0.0)$ & $30(40.5)$ & $27(36.5)$ & $6(8.1)$ & 74 \\
2000 & $1(1.4)$ & $24(34.8)$ & $22(31.9)$ & $4(5.8)$ & 69 \\
2005 & $6(1.6)$ & $113(29.7)$ & $160(42.0)$ & $48(12.6)$ & 381 \\
2010 & $11(1.4)$ & $164(21.2)$ & $207(26.8)$ & $365(47.3)$ & 772 \\
2012 & $14(1.9)$ & $158(21.0)$ & $275(36.6)$ & $291(38.7)$ & 752 \\
2014 & $5(0.4)$ & $233(18.6)$ & $353(28.2)$ & $640(51.1)$ & 1252 \\
$1992-2014$ & $169(1.9)$ & $2251(24.7)$ & $2982(32.7)$ & $3227(35.4)$ & 9114 \\
\hline
\end{tabular}

Note: percent of total number of approval in the parentheses. Source: Korea EXIM bank database. 
Regarding the accumulated number of overseas enterprises, small and medium-sized enterprises (SMEs) accounted for 46.6 percent of Korea's FDI in the world, while they took up 60 percent in Vietnam as of 2014. That is, SMEs have played a significant role in Korea's FDI in Vietnam ${ }^{5}$. The relatively active performance of SMEs in Korea's investment in Vietnam can be attributed to the following reasons. First and foremost, compared with large enterprises, SMEs usually seek cheap labor as their primary purpose of investing abroad [21]. Vietnam provides such an investment opportunity with its low wage level. Second, many producers in the garment industry were SMEs in Korea, particularly during the 1990s. As producers in a declining industry, they tried to invest abroad to continue their production, and corresponding investment outlets were found in China and Vietnam, among others.

Despite the successes of many Korean firms investing in Vietnam, there have also been many cases of failures. Such failures arose mainly from Korean investors' lack of information, working with incompetent investment partners in Vietnam or investment decisions being driven not by economic motives, but by political considerations [9].

\section{The Impact of Korea's FDI on the Vietnamese Economy}

The rising significance of Korea's FDI in Vietnam can be attributed, among others, to the government policies of the two countries and the cheap and efficient labor in Vietnam. The reformative legislation of Vietnam to open its economy together with the policy of Korea allowing OFDI in the late 1980s facilitated the flow of investment from Korea to Vietnam. In addition to the policy developments, the Vietnamese economy provided a developed infrastructure in designated areas. Further improvements in the Vietnamese economy, such as the accession to the ASEAN and WTO, stimulated not only Korea's OFDI but also investments from many other countries, mostly in Asia. Consequently, Korea's FDI in Vietnam has grown extensively over the years, influencing the Vietnamese economy through various channels, like economic growth, employment generation and the transfer of technologies.

Among others, FDI inflows have contributed to Vietnam's economic growth measured by its GDP. Although the ratio of FDI inflows to GDP had been less than 1 percent in the late 1980s, it reached 5.2 percent in 2013. The contribution rate of the foreign-invested sector in the GDP actually grew from 6.3 percent in 1995 to 13.3 percent in 2000 and reached 19.5 percent in 2013, supporting the validity of this argument. [22] estimation results showed that FDI had a positive effect on labor productivity and economic growth in Vietnam. [11] data for Vietnam's provinces showed that FDI, together with domestic investment, human capital, labor force and international trade, had positive effects on economic growth.

The majority of FIEs' outputs in Vietnam were exported; consequently, the

${ }^{5}$ Source: Korea EXIM Bank database 
trade dependence ratio ${ }^{6}$ of Vietnam continued to rise with the increase in FDI inflows. Together with FDI inflows, export expansion has often been mentioned as the major cause of Vietnam's rapid economic growth. In addition, the rapid expansion of export values contributed to changing the structure of trade from deficits to balanced trade in general ${ }^{7}$. In this sense, FDI inflows have contributed to economic growth via its effect on export expansion. The Korean firms' contribution to Vietnam's export expansion is conspicuous. For instance, just one Korean firm, Samsung Electronics, accounted for about one-sixth of Vietnam's total export values in 2014 [9].

The effect of foreign-invested firms on Vietnam's employment generation may be controversial. Foreign firms accounted for about 3 percent of Vietnam's employed population during 2005-2013, which was smaller than the 10 percent share of the state sector. In the meantime, the non-state sector was responsible for 85 percent of the employed population. The reason behind such minor performance of foreign firms in employment generation is that the investments were concentrated in activities that do not involve much job creation. They were related either to the final production stage after the importation of components and raw materials or to other capital-intensive sectors that result in a low level of domestic employment generation [17].

Meanwhile, since the primary sector employs a great proportion of workers in Vietnam, the fact that foreign-invested enterprises (FIEs) explain 3 percent of the total employment may be interpreted in the sense that FIEs generate a significant proportion of value-added jobs in the manufacturing and service sectors. Furthermore, the employment effect of Korean firms is expected to be quite large regarding the fact that the majority of Korean SMEs in Vietnam produce outputs in the labor-intensive industries, typically hiring local laborers on a largescale in the production process [20].

Although its effect differed depending on the sector, the Vietnamese economy received advanced technologies to a certain extent through FIEs. Many sectors benefitting from FDI inflows were related to medium- and high-technology manufacturing and were also positively dependent on the sector's absorptive capacity and larger amount of human capital [23]. The Korean FIEs inter alia appear to have benefitted Vietnam in the sense that Korean OFDI is mostly centered on the garment, footwear, metal and electronics industries, in which technology transfer occurs at a high level [18]. However, impediments to the technology spillover effect of FDI remain, such as the market-stealing effect of foreign firms [23].

\section{Policy Implications}

The experience of Vietnam in attracting FDI presents notable implications not only for Vietnam, but also for other developing economies. By referring to Viet-

${ }^{6}$ It is defined as (export values + import values)/GDP.

${ }^{7}$ The import values had been about 2.5 times larger than the export values in 1986 and 1987. Meanwhile, they converged to about USD 132 billion in 2013. 
nam's economic reforms and FDI liberalization, other governments may introduce policies that promote FDI inflows and enhance the effect of FDI on their economies.

First, the case of Vietnam stresses the important role of economic liberalization policies consisting of integration into the world economy and FDI-friendly measures. Vietnam's efforts to comply with the global economic standards through its BTA with the US and accession to the WTO led to the surge in FDI inflows in the 2000s. This shows that the benefits of integrating into the global economy do not end merely with the preferential treatments provided by the individual agreements but extend further to increased interactions with other economies and enhanced attractiveness of the economy concerned to foreign investors. Furthermore, more direct contributions have come from the FDI promotion policies of the Vietnamese Government since the late 1980s, which have greatly benefitted Vietnam's FDI inflows since the early 1990s. Thus, the policy reforms in the host country to create a better investment climate for foreigners are crucial in increasing FDI inflows to their economy.

Second, the regional distribution of FDI in Vietnam shows the significance of the developed infrastructure and incentives provided by EPZs and IZs in promoting FDI inflows. Although the situation of Vietnam, where FDI inflows are mostly concentrated in the EPZs and IZs, indicates the importance of developing such economic zones, other supportive cases exist, such as China's special economic zones (SEZs). The positive role that these zones play in attracting FDI has proved to be significant due to their developed transportation and telecommunications that facilitate business activities and the tax incentives provided to foreign firms operating in those zones. However, the governments of the host countries should consider extending such economic zones to areas other than those developed in the initial stage. That is, Vietnam's current situation shows problems such as rising production costs and operational difficulties in the Hanoi and Ho Chi Minh City areas due to the excessive concentration of FDI in those two cities, which are also hardships faced by Korean investors in Vietnam. Thus, the case of Vietnam also indicates the necessity of building SEZs and improving the infrastructure in less developed regions for continued success in attracting $\mathrm{FDI}^{8}$.

Third, the importance of human resources is noteworthy in attracting FDI. The attractiveness of Vietnam's labor force came not only from its low wage level but also from its high quality, represented by Vietnam's education level ${ }^{9}$. For instance, the adult literacy ratereached 90 percent in 1999 and 94 percent in 2009 [24]. Such cost-efficiency of Vietnamese labor has also enabled Korean investors to invest in various economic activities involving the electronics industry, which requires workers with relatively advanced techniques compared with the other

\footnotetext{
${ }^{8}$ Source: interview with the Vietnamese government officials attending the Strengthening the Capabilities of Trade and FDI Workshop held on 6 March 2015 at the Korea Trade-Investment Promotion Agency in Seoul.

${ }^{9}$ Source: interview with the staff members of Korea International Cooperation Agency in Hanoi Office, Mr. Shik-Hyun Kim and Ms. Sooyoung Choi, on 7 July 2015 in Hanoi.
} 
industries in the manufacturing sector. Thus, the governmental efforts of the host country to improve its human resources through better education would be crucial in attracting and sustaining FDI inflows. Nevertheless, regarding the fact that Vietnam's compulsory education is still restricted to 5 years of elementary school education [9], there appears to be much room for improvement in the level of human resources of Vietnam despite its superiority compared with that in the neighboring countries.

Fourth, the sectorial change in Korea's OFDI in Vietnam among the sub-categories of the manufacturing sector indicates the necessity of reflecting the host country's development level in attracting FIEs. Korean investment in Vietnam has generally moved from garments and footwear to electronics and metal in the 2010s. Such changes in the investment trend are the consequence of Vietnam's economic development over the years, which enabled the production of more valued manufactured products requiring more advanced technologies compared with the 1990s and early 2000s. Thus, it is important for the government to assess the development level of its economy precisely and focus on attracting FDI to the sectors reflecting its changing pattern of comparative advantage.

\section{Conclusions}

The Vietnamese economy has shown very rapid economic growth since Doi Moi. In the meantime, a huge amount of FDI has flowed into Vietnam. Korea's OFDI in Vietnam deserves attention in the sense that Korea is its leading investor. The pre-eminence of Korean OFDI in Vietnam has been the consequence of multiple events. First, the policy changes in both governments promoting FDI inflows and allowing OFDI since the late1980s have contributed to the surge of investment flows from Korea to Vietnam. Second, Vietnam has provided an alternative to China, where the wage level has risen and related regulations have become stricter. That is, Vietnam has been able to replace China partly through its cost-efficient labor force with a low wage and a high level of education. Third, Vietnam's growing middle class due to its rapid economic growth has made the Vietnamese market more attractive to Korean investors. Although the traditional motive of Korean firms was to take advantage of Vietnam's export incentives, investors' attention has been redirected towards targeting the local market of Vietnam. Fourth, Vietnam has provided a developed infrastructure and tax incentives in its special zones, where Korea's OFDI has mostly been located.

Vietnam's rapid economic growth can partly be attributed to FDI inflows, of which Korean OFDI constitutes a large share. The contribution of Korean firms to Vietnam's employment generation has been particularly large in light of the pre-eminent share of SMEs in Korea's OFDI in Vietnam. Although there are some remaining problems to overcome to maximize the technology spillover effect of FIEs, Korean firms appear to have contributed significantly by transferring advanced technology to Vietnam due to the particularly high level of technology transfers in the electronics and metal industries. Korea's OFDI in Vietnam has also contributed to Vietnam's further industrial development from 
low-value-added to high-value-added industries.

Vietnam has been successful in actively launching and benefitting from FDI over the last three decades. Nevertheless, problems such as the lack of human resources with advanced technologies together with corruption remain in the Vietnamese economy and are perceived to be highly burdensome to foreign investors. Although Korea's OFDI in Vietnam is expected to continue with the ratification of the Korea-Vietnam FTA and the 2020 infrastructure-related FDI launching plan of the Vietnamese Government [25], Vietnam can enhance the FDI inflows further by overcoming the remaining problems in its economy, strengthening the level of human capital and sustaining its investor-friendly policies.

\section{References}

[1] Tien, Q.T. (2008) Reforms in FDI Policy and the Investment Climate in Vietnam. Journal of World Trade, 42, 1179-1202.

[2] Export Import Bank of Korea (EXIM Bank) (2008) Vietnam: Current State and Development Plan. EXIM Bank, Seoul. (In Korean)

[3] Tien, Q.T. (2009) Sudden Surge in FDI and Infrastructure Bottlenecks: The Case in Vietnam. ASEAN Economic Bulletin, 26, 58-76. https://doi.org/10.1355/AE26-1E

[4] United Nations Conference on Trade and Development (UNCTAD) (2008) World Investment Report. United Nations, New York and Geneva.

[5] UNCTAD (2015) World Investment Report. United Nations, New York and Geneva.

[6] EXIM Bank (2015) 2015 Investment Climate Risk Assessment. EXIM Bank, Seoul. (In Korean)

[7] UNCTAD (2008) Investment Policy Review: Vietnam. United Nations, New York and Geneva.

[8] Jeon, B.N. and Ahn, S.Y. (2004) Multinational Corporations and Host Country Receptivity: Perceptions from the Three Asian Countries. Multinational Business Review, 12, 17-36. https://doi.org/10.1108/1525383X200400008

[9] Kim, S.H. (2015) Understanding Vietnam. Yeonhap News Press, Seoul. (In Korean).

[10] Govil, M. (2013) Determinants of Inward FDI in Developing Countries: Evidence from a Time Series Data Analysis. Anvesha, 6, 22-29.

[11] Hoang, T.T., Wiboonchutikula, P. and Bangorn, T. (2010) Does Foreign Direct Investment Promote Economic Growth in Vietnam? ASEAN Economic Bulletin, 27, 295-311. https://doi.org/10.1355/ae27-3d

[12] UNCTAD (2006) World Investment Report. United Nations, New York and Geneva.

[13] Gill, A. (2014) Internationalization of Firms: An Analysis of South Korean FDI in India. Seoul Journal of Economics, 27, 87-114.

[14] EXIM Bank (2009) OFDI Trend. EXIM Bank, Seoul. (In Korean)

[15] EXIM Bank (2010) OFDI Trend. EXIM Bank, Seoul. (In Korean)

[16] EXIM Bank (2011) OFDI Trend. EXIM Bank, Seoul. (In Korean)

[17] Son, S.H. (2005) Vietnam: Effects of FDI and Remaining Tasks. EXIM Bank, Seoul. (In Korean)

[18] Kwak, J.S. (2007) Korean OFDI: Investment Strategies and Corporate Motivations 
for Investing Abroad. United Nations, Santiago.

[19] EXIM Bank (2004) Vietnam: Strengthening the Local Government Authority in Approval of FDI. EXIM Bank, Seoul. (In Korean)

[20] EXIM Bank (2011) 2010 OFDI Business Analysis. EXIM Bank, Seoul. (In Korean)

[21] UNCTAD (2007) World Investment Report. United Nations, New York and Geneva.

[22] Vu, T.B. (2008) Foreign Direct Investment and Endogenous Growth in Vietnam. Applied Economics, 40, 1165-1173. https://doi.org/10.1080/00036840600749433

[23] Anwar, S. and Nguyen, L.P. (2010) Absorptive Capacity, Foreign Direct Investmentlinked Spillovers and Economic Growth in Vietnam. Asian Business and Management, 9, 553-570. https://doi.org/10.1057/abm.2010.28

[24] World Bank (2015) World Development Indicators 2015. World Bank, Washington DC.

[25] EXIM Bank (2014) Vietnam's 2020 Plan on Attracting Foreign Capital. EXIM Bank, Seoul. (In Korean).

Submit or recommend next manuscript to SCIRP and we will provide best service for you:

Accepting pre-submission inquiries through Email, Facebook, LinkedIn, Twitter, etc. A wide selection of journals (inclusive of 9 subjects, more than 200 journals)

Providing 24-hour high-quality service

User-friendly online submission system

Fair and swift peer-review system

Efficient typesetting and proofreading procedure

Display of the result of downloads and visits, as well as the number of cited articles

Maximum dissemination of your research work

Submit your manuscript at: http://papersubmission.scirp.org/

Or contact ojbm@scirp.org 